\title{
Student Perception of Thermal Comfort of Outdoor Space in Nusa Nipa University, Maumere, East Nusa Tenggara
}

\author{
Cornelia Hildegardis ${ }^{1 a, b^{*}}$, Anak Agung Ayu Oka Saraswati ${ }^{2}$, I Dewa Gede Agung Diasana ${ }^{3}$ and Ni \\ Ketut Agusinta Dewi ${ }^{4}$ \\ 1a Student of Doctoral Program Engineering Science, Udayana University, Denpasar, Bali, Indonesia
${ }^{1 b}$ lecture of Architecture Department Nusa Nipa University, Maumere, East Nusa Tenggara, Indonesia
*Email: childegardis4@gmail.com

${ }_{2,3,4}$ lecture of Doctoral Program Engineering Science Udayana University, Denpasar, Bali, Indonesia
}

Abstract Nusa Nipa University is one of a number of universities in Maumere City, Sikka Regency, East Nusa Tenggara. Based on the Koppen climate classification, the City of Maumere is included in the savanna. The savanna climate is different from the tropical rain climate in terms of temperature, air humidity and wind speed. The high temperature in this city influences the perception of thermal comfort. Thermal comfort is a necessity for people performing activities in both outside and inside of building, one of those are students at Nusa Nipa University. This research was conducted by distributing questionnaire to 50 students occupying in 2 (two) different spots in the outdoor space. The result showed that $58 \%$ students felt comfortable in the grassy area with shade compared to other off-campus areas. This perception of comfort is influenced by comfort factors namely hardscape or softscape that exist in the outdoor space of the Nusa Nipa University.

Index Terms-Perception, Thermal Comfort, Outdoor space, and Nusa Nipa University .

\section{INTRODUCTION}

$\mathrm{H}$ umans need comfortable enviromnent in performing their activities. Comfort is a perceived umans comphrehensive assessment towards the environment that includes space comfort, visual comfort, hearing comfort and thermal comfort [1].

ASHRAE Standard 55-1992 defines thermal comfort as the state of mind that expresses satisfaction with the thermal environment. This standard also states that the accepted thermal condition requires $90 \%$ of occupants feel satisfied. McIntyre [2] notes that a person considered feeling thermal comfort is when they neither feel hot nor cold in their environment. Sangkertadi [3] states that outdoor comfort is harder to assess compared to indoor comfort. One of the assessable environment in terms of thermal comfort is outdoor space in universty area.

Nusa Nipa University (UNIPA) is a university in Maumere City, Sikka Regency, East Nusa Tenggara, Indonesia. Based on Koppen climate classification, Maumere is categorized as savanah/dry city. The high temperature in
Maumere city influences people's perception of comfort, particularly thermal comfort.

Thermal comfort is a neccessity for people performing outdoor activities. As a space for activities, outdoor space in UNIPA should be able to achieve thermal comfort level. Hence, indetification and study on comfortable or uncomformtable outdoor space in terms of thermal comfort is needed.

\section{A. Thermal Comfort}

Thermal comfort is a process that involves physical, physiological and psycological assessment. Therefore, thermal comfort is the percieved condition of mind that expresses satisfaction on the thermal environment [4].

\section{B. Thermal Comfort in Outdoor Space}

According to Istiawan and Kencana [5]. Outdoor space is space constructed by limiting nature on flooring and wall, whereas ceiling (overhead cover) in unlimited. Thus, in outdoor space planning, flooring and wall elements become crucial.

Outdoor space is a generic term that consists of open space. Open space is one part of outdoor space comprises of certain limits, along with function, purpose and human 
will. Those limits are marked by frame that transform into a positive space [6].Futher, park is a part of outdoor space.

According to Sangkertadi [3], one of a contributing factors that greatly influences outdoor space comfort is air temperature. The existence of parks in an area could increase air humidity at night and lower the rising temperature at day time [7]. Parks are not only useful in ecological, social, cultural economy and aestical aspects, but also in micro climate in the area.

A comfortable outdoor space tends to have colorful buildings, wide setback, lots of shady trees, paved floorings, plenty sets of street furnitures, and enclosed sky view factor [8]. Further, micro climate condition could also influence comfort sensation experienced by visitors in that area [7].

\section{Outdoor Space Elements in Improving Thermal Comfort}

Visitor comfort serves as a prerequisite to supporting activities in parks [9]. Additionally, the neccessary comfort required in parks include physical and psychological comfort. Physical comfort is the freedom to use facilities without interference. Moreover, psychological comfort is a feeling of being safe and protected from disturbing weather [10].

Trees or greenery is the most significant element perceived as a visual aspect. Greenery acts as a supporting facility that gives calmness in planning a lively and comfortabale outdoor space in terms of thermal comfort [11]. According to [1], planting greenery in front of buildings could provide a sense of comfort and cool.

\section{Thermal Comfort Perception on Outdoor Space}

Acording to [12], the process of perception requires individuals to provide an assessment of an object that has meaning to them. Respondents' perception of outdoor space can be indicated by noticing changes in air temperature and humidity felt when either the outdoor space is covered with canopy or only with pavement [13].

\section{METHOD}

This research was conducted in the outdoor space of Nusa Nipa University. The outdoor space was divided into 2 (two) areas: one space with pavement and no shade, the other has grass (grassy) with shade covering $50 \%$ of the space.

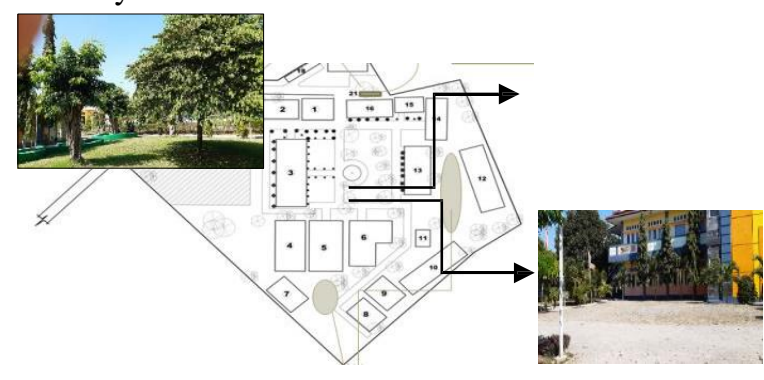

Fig 1. Research Area

Source: Personal Documentation, 2019

This research surveyed 50 students/respondents studying or having discussion in each outdoor space area, making a total of 100 respondents. Whereas 50 students in the grassy area with shade and another 50 students in the pavement area without shade.

Questionnaire and quick interview were conducted to collect perception data from respondents. Digital thermometer and digital Anemometer were used to measure external environmental factors that affect the comfort felt externally by respondents. Both measurements were conducted simultaneously.

Each student was asked to fill in the questionnaire provided with regard to perception using the Bedford Scale. Questionnaires were filled out from morning until noon (08.00 AM - 02.00 PM).

The distributed questionnaires contained questions about respondents' data and perception of weather comfort felt in the particular point of place. Data obtained were then analyzed by simple statistics to determine scores of comfort, acceptance and preferences.

\section{RESULT AND DISCUSSION}

\section{A. General Description of research Area}

Nusa Nipa University (UNIPA) is a university located in Maumere City, Flores, Nusa Tenggara Timur. In addition to collage buildings, UNIPA also has outdoor space consisting of green open space and parks. Some of the trees planted are: Palem Putri/Pasific Palm (Veitchia merillii), Kersen/Jamaica Cherry (Mutingia calabura) and Glodokan Tiang/False Ashoka (Polyalthia longifolia)

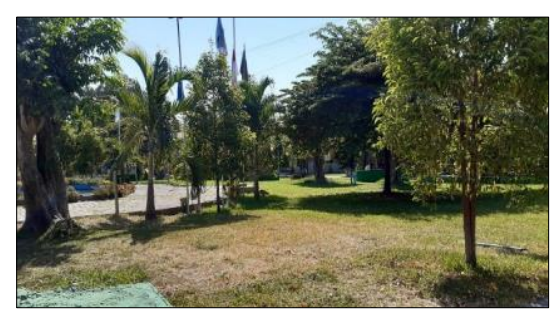

Fig 2. Few Trees in UNIPA Outdoor Space Source: Personal Documentation, 2019 
These trees are used for students to socialize and study.

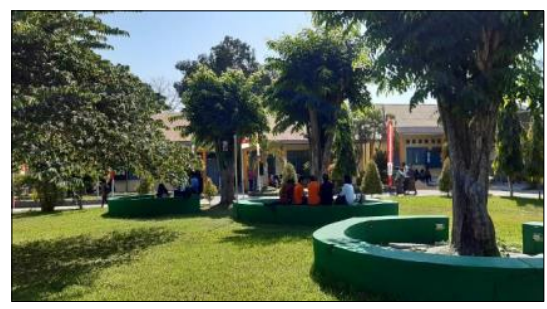

Fig 3. Outdoor Space For Student Activities

Source: Personal Documentation, 2019

The majority of students/respondents interviewed in the UNIPA outdoor space were students who had lived in Maumere for more than 2 years and were between 19-22 years of age.

\section{B. Student Perception of Comfort Towards UNIPA Outdoor Space}

Based on measurement from thermometer and anemometer, it was then discovered that the highest temperature in pavement area without shade was $35.4^{\circ} \mathrm{C}$ and the hightest was $28.6^{\circ} \mathrm{C}$. While in grassy area with shade, the highest temperature was $30.50^{\circ} \mathrm{C}$ and the lowest was $27.6^{\circ} \mathrm{C}$.

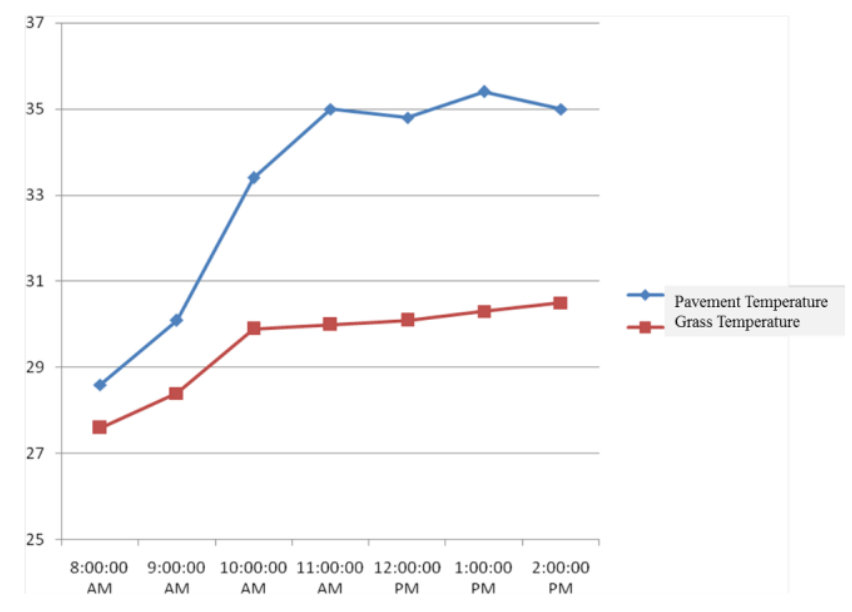

Fig 4. Temperature Graph of UNIPA Outdoor Space Source: Personal Analysis, 2019

This research found that temperature in grassy area with shade was lower of approximately $3.18^{\circ} \mathrm{C}$ compared to pavement area without shade. According to [13], grass material can absorb heat better when compared to pavement area.

Data obtained from questionnaires noted that in the pavement area without shade, students felt comfortably hot in the temperature range of $28.6^{\circ}-30.1^{\circ} \mathrm{C}$; and felt extremely hot in the temperature range of $33.4^{\circ} \mathrm{C}-35.4^{\circ} \mathrm{C}$. While in the grassy area with shade, it was discovered that $58 \%$ students felt comfortable in the temperature range of $27.6^{\circ} \mathrm{C}-29.9^{\circ} \mathrm{C}$ and felt hot in $30^{\circ} \mathrm{C}$.

Pavement area without shade had a lower score of humidity when compared with its higher temperature. The humidity score of this area ranged from $37.6 \%-48.9 \%$, (and when the air temperature reached intense heat) caused students to feel uncomfortable.

The high temperature and the low humidity in the area are influenced by several factors such as softscape and hardscape.

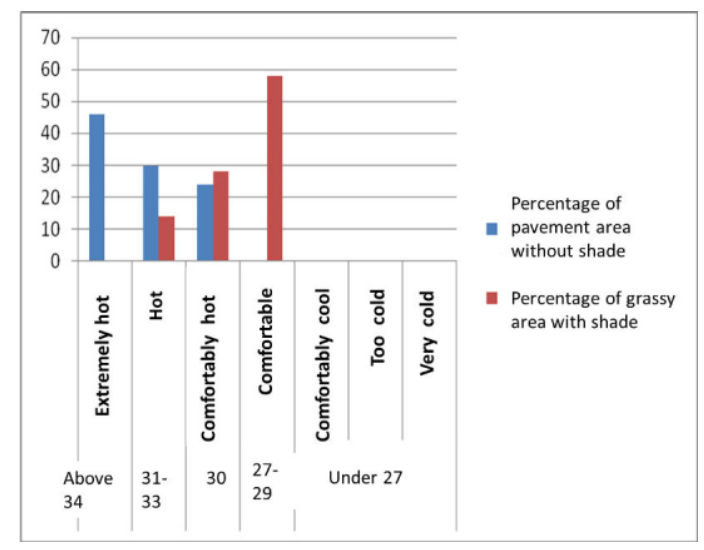

Fig 5. Percentage of Student Comfort Towards UNIPA Outdoor Space Source: Personal Analysis, 2019

\section{Students Adaptation Towards UNIPA Outdoor space}

Data obtained from quistionnaires handed out to respondents, it was then discovered that there were several actions taken in order to get the sense of comfort when being in outdoor space. As high as $68 \%$ of respondents chosed to drink cold beverages when they felt hot, $17.8 \%$ chosed to move from their previous spot, and $14.2 \%$ chosed to do nothing from the discomfort felt.

\section{CONCLUSION}

Based on analysis, this research conluced that temperature had influence on students comfort. The high and low degrees of temperature and scores of air humidity were determined by elements in the areas. Students felt more comfortable in the grassy area with shade (softscape) compared to pavement area without shade (hardscape).

This result is line with the statement from [9], that the higher the air temperature, the lower the air humidity score. Several factors that influence air humidity score are, among others: the availability of vaporizer, air temperature and solar radiation [14].

\section{REFERENCES}

[1] Handayani, M. (2016). Persepsi Masyarakat terkait Kenyamanan Termal di Permukiman Padat (Non-AC) Kecamatan Dukuh Pakis Kota Surabaya. Swara Bhumi, 4(2), 1-7.

[2] McIntyre, D. A. (1980). Indoor Climate: Applied Science. 
[3] Sangkertadi, S. (2013). Kenyamanan Termis di Ruang Luar Beriklim Tropis Lembab. Bandung: Alfabeta.

[4] Sugini. (2004). Pemaknaan Istilah- Istilah Kualitas Kenyamanan Thermal Ruang Dalam Kaitan Dengan Variabel Iklim Ruang. LOGIKA, 1(2).

[5] Istiawan, S., \& Kencana, I. (2016). Ruang. Jakarta: Griya Kreasi.

[6] Ashihara, Y. (1974). Perancangan Eksterior dalam Arsitektur (terjemahan). Bandung: Abdi Widya.

[7] Suyono, B., \& Prianto, E. (2017). Kajian Sensasi Kenyamanan Termal Dan Konsumsi Energi Di Taman Srigunting Kota Lama Semarang. Modul, 17(2), 17-25.

[8] Rahtama, A. P. (2014). Kenyamanan Termal Ruang Luar Di Koridor Jalan Tugu-Kraton Kota Yogyakarta. Universitas Gadjah Mada, Yogyakarta.

[9] Mariski, Nasrullah, N., \& Gunawan, A. (2017). Perceptions And Preferences Of User To The Thermal Comfort In Menteng Park And Honda Tebet Park. Jurnal Lanskap Indonesia, 24-35. doi:10.29244/jli.2017.9.1.24-35.

[10] Baskara, M. (2012). Prinsip Pengendalian Perancangan Taman Bermain Anak Di Ruang Publik. Jurnal Lanskap Indonesia, 3(1). doi:10.29244/jli.2011.3.1.\%p.

[11] Binarti, F., Kusuma, H. E., Wonorahardjo, S., \& Triyadi, S. (2018). Peranan Unsur-Unsur Ruang Terbuka Pada Tingkat Kenyamanan Termal Outdoor: Antara Persepsi Dan Pengetahuan. Komposisi, 12(1).

[12] Allport, F. H. (2013). Theories of Perception and the Concept of Structure with an Introduction to a Dynamic Structural Theory of Behavior: Literary Licensing, LLC.

[13] Sumarsono, A. R., Baskara, M., \& Sitawati, S. (2016). Evaluasi Kenyamanan Taman Jalur Hijau Di Kota Surabaya (Studi Kasus : Jalan Raya Darmo). Jurnal Produksi Tanaman.

[14] Handoko, H. (1995). Klimatologi dasar : landasan pemahaman fisika atmosfer dan unsur- unsur iklim. Jakarta: Pustaka Jaya. 